\title{
A traumatic false aneurysm of the ankle: an unusual bump on the forefoot
}

Hugo T C Veger, Willem-Maarten Bosman, Maartje A van den Broek, Ewan D Ritchie, Paul Ph Hedeman Joosten

Department of Surgery, Rijnland Ziekenhuis, Leiderdorp, The Netherlands

\section{Correspondence to}

Dr Ewan D Ritchie, e.ritchie@rijnland.nl

Accepted 7 August 2014
CrossMark

To cite: Veger HTC, Bosman W-M, van den Broek MA, et al. BMJ Case Rep Published online:

[please include Day Month Year] doi:10.1136/bcr-2014205955

\section{DESCRIPTION}

A 66-year-old man was referred to the general surgeon by his general practitioner for excision of a 'bump' on the anterior side of his left ankle because of pain due to irritation from shoe gear. This 'bump' slowly started since several months after an ankle injury. He denies intravenous access or previous surgery in this region of the ankle. Medical history represents obesity, atrial fibrillation, chronic obstructive pulmonary disease and diabetes mellitus type 2. Physical examination of the left ankle revealed an elevated, weak pulsatile mass approximately $2 \mathrm{~cm}$ in diameter. It was located along the anterior side of the left ankle in the anatomical region of the dorsalis pedis artery (DPA). MR angiography and MRI (figure $1 \mathrm{~A}, \mathrm{~B}$ ) and duplex ultrasound (figure 1C) showed a round pulsatile lesion just outside the DPA at the level of the tibiotalar joint confirming the diagnosis of false aneurysm of one of the side branches of the DPA. Arteriogram of the left lower extremity (figure 1D) confirmed the diagnosis of a pseudoaneurysm arising from the anterior tibial artery as it crossed tibiotalar joint with slight compression of the DPA.

As the patient suffered pain from the pseudoaneurysm, it was decided to remove it surgically. The pseudoaneurysm was approached with a lazy S incision (figure 2A). The aneurysm was filled by a small side branch of the DPA, which was ligated (figure 2B). The aneurysm was opened and was filled with clot (figure 2C). When
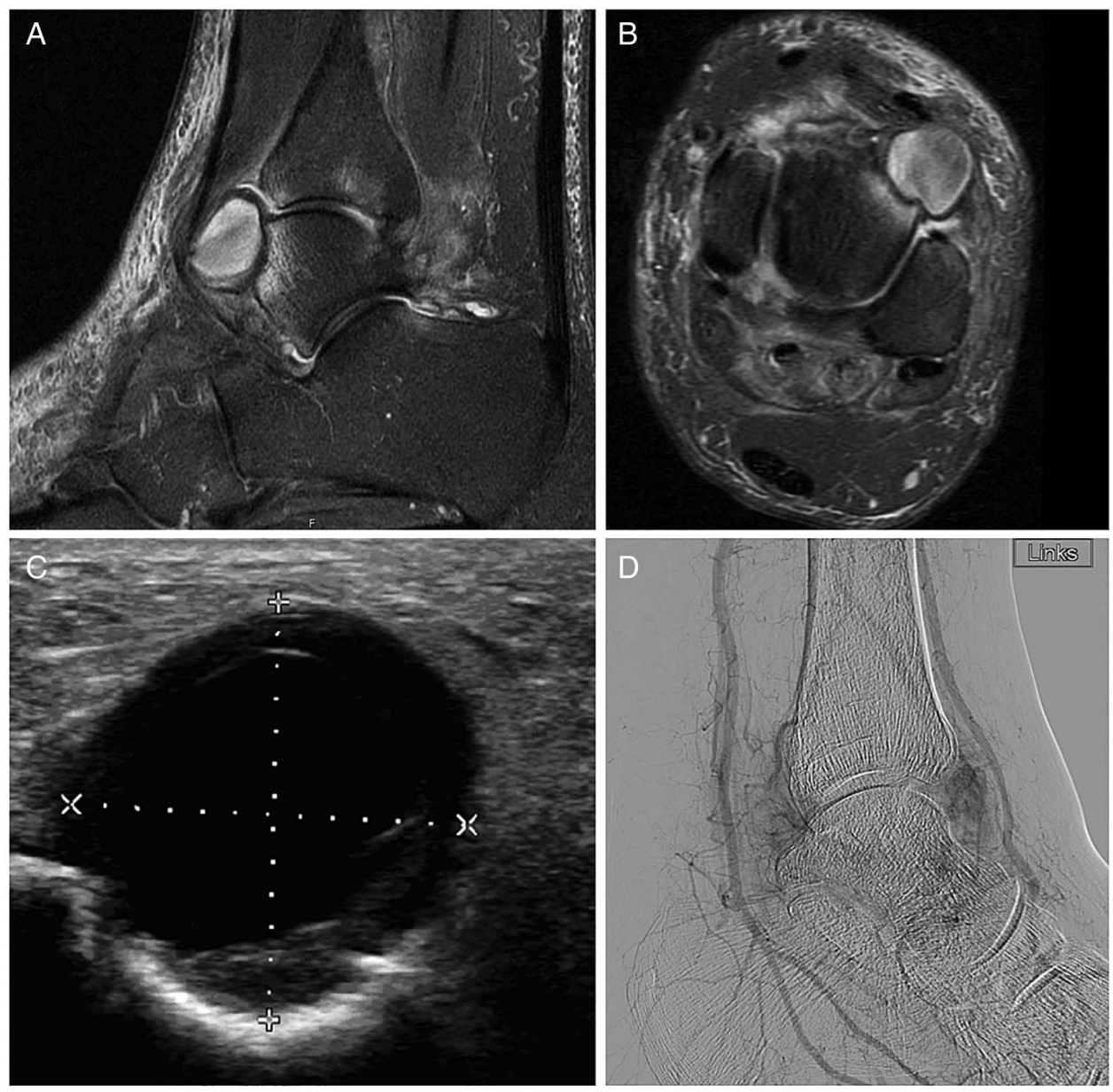

Figure 1 Preoperative imaging: ( $A$ and $B$ ) MRI showing a $2 \mathrm{~cm}$ tumour ventral of the tibia and the talus. (C) Duplex ultrasound showing a patent lumen. (D) Arteriogram showing a pseudoaneurysm of a side branch of the dorsal pedis artery. 
Figure 2 The pseudoaneurysm was approached through a lazy $S$ incision (A). After adequate exposure (B), the pseudoaneurysm was opened and removed (C). After removal of the pseudoaneurysm, the talar head became visible with complete destruction of the cartilage (D).
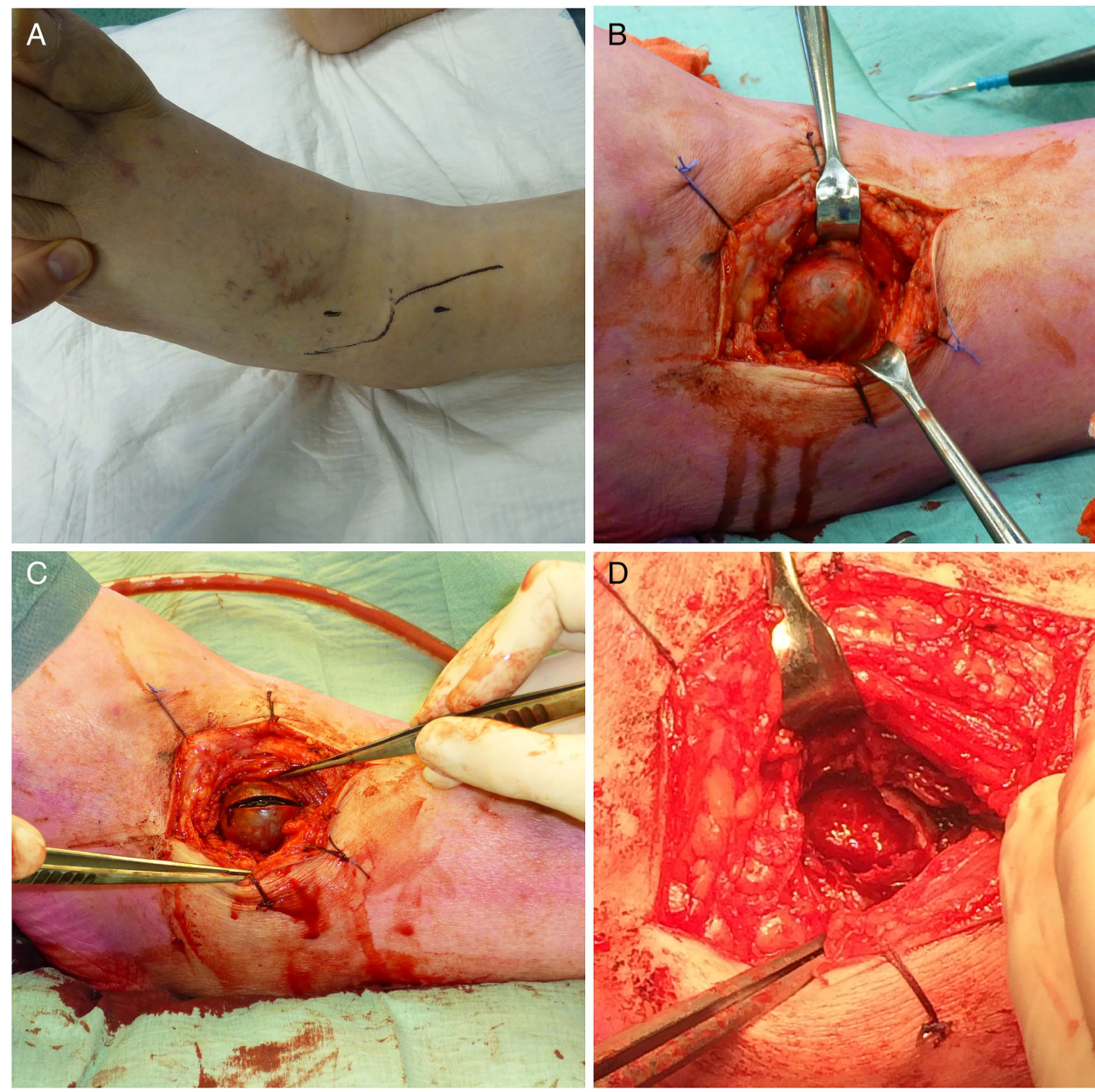

the pseudoaneurysm was removed, it showed a complete destruction of the ventral cartilage of the talus (figure 2D). The orthopaedic surgeon was consulted and it was decided not to fill the defect.

Pseudoaneurysm, also known as a false aneurysm, is the result of trauma to all three layers of an artery resulting in extravasation of blood, and the formation of a fibrous tissue capsule containing blood flowing outside the injured vessel lumen. This fibrous capsule is void of the natural three-layer architecture of a true aneurysm and expands until confined by the limits of adjacent structures, and is therefore more likely to rupture than true aneurysms. ${ }^{1}$ Pseudoaneurysms are usually iatrogenic in origin but has been known to arise from trauma. ${ }^{1}$ Anatomically, the anterior tibial artery is in close proximity to the anterior ankle joint capsule at the level of the talar neck, and runs deep down the superior and inferior retinaculum. Uncommon complications that have been described in the literature after pseudoaneurysms in the foot and ankle include haemarthrosis of the ankle and compartment syndrome. ${ }^{2}$ Treatment depends on the particular vessel affected and may involve prolonged ultrasound-guided compression, thrombin injection, ${ }^{3}$ resection of the pseudoaneurysm with interpositional vein grafting or endovascular stenting. Thrombin injection is the initial treatment of choice when possibile, as it is less invasive than the other treatment options.

\section{Learning points}

- Ankle injury can result on the long term in pseudoaneurysm formation.

- Pseudoaneurysm must be in the differential diagnosis of soft tissue mass at the ankle.

- Untreated pseudoaneurysms may lead to destruction of the adjacent cartilage.

Acknowledgements The authors would like to acknowledge $S$ Bouwmeester for her help with the acquisition of the perioperative photographs.

Competing interests None.

Patient consent Obtained.

Provenance and peer review Not commissioned; externally peer reviewed.

\section{REFERENCES}

1 van Hensbroek PB, Ponsen KJ, Reekers JA, et al. Endovascular treatment of anterior tibial artery pseudoaneurysm following locking compression plating of the tibia. J Orthop Trauma 2007;21:279-82.

2 Ward NJ, Wilde GP, Jackson WF, et al. Compartment syndrome following ankle sprain. J Bone Joint Surg Br 2007;89:953-5.

3 Pezzullo JA, Dupuy DE, Cronan JJ. Percutaneous injection of thrombin for the treatment of pseudoaneurysms after catheterization: an alternative to sonographically guided compression. AJR Am J Roentgenol 2000;175:1035-40. 
Copyright 2014 BMJ Publishing Group. All rights reserved. For permission to reuse any of this content visit http://group.bmj.com/group/rights-licensing/permissions.

BMJ Case Report Fellows may re-use this article for personal use and teaching without any further permission.

Become a Fellow of BMJ Case Reports today and you can:

- Submit as many cases as you like

- Enjoy fast sympathetic peer review and rapid publication of accepted articles

- Access all the published articles

- Re-use any of the published material for personal use and teaching without further permission

For information on Institutional Fellowships contact consortiasales@bmjgroup.com

Visit casereports.bmj.com for more articles like this and to become a Fellow 